\title{
Erratum to: Monitoring antigenic protein integrity during glycoconjugate vaccine synthesis using capillary electrophoresis-mass spectrometry
}

\author{
Sara Tengattini ${ }^{1,2}$ - Elena Domínguez-Vega ${ }^{2}$ Luciano Piubelli ${ }^{3,4} \cdot$ Caterina Temporini $^{1}$. \\ Marco Terreni $^{1}$ - Govert W. Somsen ${ }^{2}$
}

Received: 27 October 2016 / Accepted: 27 October 2016/Published online: 9 November 2016

(C) Springer-Verlag Berlin Heidelberg 2016

\section{Erratum to: Anal Bioanal Chem}

DOI 10.1007/s00216-016-9723-5

Unfortunately the name of Luciano Piubelli was missing as co-author of this contribution. The correct list of authors is: Sara Tengattini, Elena Domínguez-Vega, Luciano Piubelli, Caterina Temporini, Marco Terreni, Govert W. Somsen

The online version of the original article can be found at http:// dx.doi.org/10.1007/s00216-016-9723-5.

Elena Domínguez-Vega e.dominguezvega@vu.nl

1 Department of Drug Sciences, University of Pavia, Pavia, Italy

2 Division of BioAnalytical Chemistry, Department of Chemistry and Pharmaceutical Sciences, Vrije Universiteit Amsterdam,

Amsterdam, The Netherlands

3 Department of Biotechnology and Life Sciences, University of Insubria, Varese, Italy

4 The Protein Factory Interuniversity Centre, Politecnico of Milano and University of Insubria, Milano, Italy 